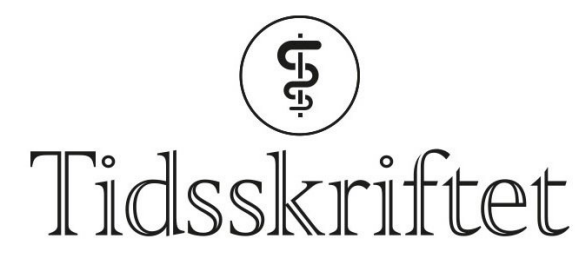

DEN NORSKE LEGEFORENING

\title{
Ottar Heggø
}

MINNEORD

LEIV M. HOVE

INGE GLAMBEK

FRANK PETTER GULLAKSEN

KNUT ROKSTAD

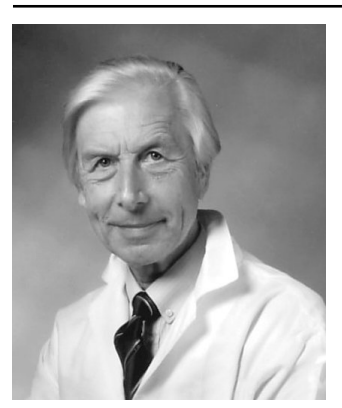

Tidligere avdelingsoverlege Ottar Heggø døde i sitt hjem i Bergen 12. april 2017, 94 år gammel. Han ble født i Stongfjorden i Askvoll kommune 18. januar 1923, tok eksamen artium i 1943 ved Firda Landsgymnas i Sandane og medisinsk embetseksamen ved Universitetet i Oslo i 1952.

Hans første legejobb var som assistent for distriktslegen i Lista åtte måneder i 1953, etterfulgt av to år som assistentlege ved Notodden sykehus, og kandidattjeneste ved Fylkessykehuset i Haugesund. Der fikk han også et halvt års vikariat ved Sanitetsforeningens Revmatismesykehus, noe som til en viss grad ble bestemmende for hans videre yrkesvalg. Hans kirurgiske utdanning brakte ham videre til Fylkessykehuset i Odda som reservelege i to år, og til Haukeland sykehus som reservelege 1959-62. Han ble spesialist i generell kirurgi i 1962.

$\emptyset$ nsket om en karriere innen akademia ble styrket i løpet av ett år som assistentlege ved Gades institutt avdeling for patologi. Og da det nyopprettede Anatomisk institutt ved Universitetet i Bergen søkte etter universitetslærere, fikk han stilling som prosektor i human anatomi. Han tilbragte de neste to årene med forskning, undervisning av medisinstudenter og oppbygging av et nytt institutt. Han utarbeidet en grundig disseksjonsveiledning til undervisningen og fikk publisert fem vitenskapelige artikler i høyt rangerte tidsskrifter, som Lancet og Acta Pathologica, om sine mikrodisseksjonsstudier av cystiske nyrer.

Savnet av klinisk kirurgi førte imidlertid til at han aldri fikk fullført sin doktoravhandling. 
Han begynte i 1965 på en ny spesialistutdanning, nå i plastikkirurgi. Først tilbrakte han $1 \frac{112}{2}$ år hos overlege Schjelderup ved Hospitalet Betanien i Bergen, deretter to år ved Sahlgrenska sjukhuset i Gøteborg og Akademiska sjukhuset i Uppsala, hvor han han fikk et nært og godt samarbeid med Sveriges fremste plastikkirurg, professor Tord Skoog. I disse årene publiserte han flere kliniske arbeider fra det plastikkirurgiske feltet, som rekonstruksjon etter ansiktsskader ved trafikkulykker, etter facialisparese o.a.

Kirurgisk utdanning på den tiden betydde mange flyttinger og oppbrudd. Familien ønsket seg tilbake til Bergen, og en reservelegestilling ved Kysthospitalet i Hagavik åpnet for det. Ombygging og utvidelse av Diakonissehjemmets klinikk Haraldsplass til offentlig sykehus i 1970 åpnet for fast stilling og spennende utfordringer med oppstart av en ny avdeling. Han virket som klinikksjef og avdelingsoverlege ved Haraldsplass i 21 år fra 1970 til 1991.

Heggøs største bidrag som kirurg var som pioner innen revmakirurgi i Hordaland. Med stipend fra Hordaland fylke reiste han til Nordens fremste senter for revmatiske sykdommer, Heinola i Finland, for ytterligere spesialistutdanning. Og da man i 1972 åpnet Revmatologisk avdeling ved Diakonissehjemmets sykehus Haraldsplass, var Heggø klar som revmakirurg, slik at Hordaland fylke kunne gi ett fullverdig tilbud til de mange pasientene med leddgikt.

I årene som sjef på Haraldsplass ledet Heggø flere ombygningsprosjekter med bl.a. ny operasjonsavdeling og poliklinikk. Han utviklet revmakirurgien i Hordaland til et høyt nivå basert på godt klinisk skjønn og fremragende kirurgisk teknikk.

Heggø fikk 25 gode år som pensjonist med god helse og tid til å dyrke sine interesser som musikk, litteratur og kunst, i tillegg til tegning og amatørmaling. Livet ble riktignok mer stusselig etter at hans sykepleierkone Borgny døde for en del år siden. De mange fjellturene sommer som vinter holdt ham i god form til det siste. Han satt på sin faste plass på torsdagskonsertene til Bergen filharmoniske orkester til et par uker før han døde.

Som tidligere kolleger ved Kirurgisk avdeling, Haraldsplass Diakonale Sykehus, er vi takknemlige for alt vi har lært av Heggø og lyser fred over hans minne.

Publisert: 22. januar 2018. Tidsskr Nor Legeforen. DOI: 10.4045/tidsskr.17.1045

(C) Tidsskrift for Den norske legeforening 2020. Lastet ned fra tidsskriftet.no 